
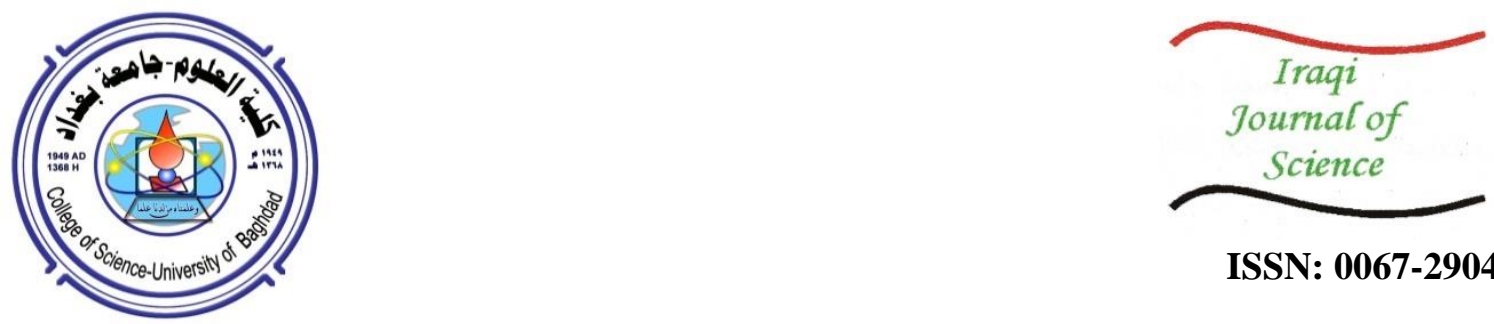

ISSN: 0067-2904

\title{
Effects of Psidium Guajava Leaves Extract on the Viability of Echinococcus Granulosus Protoscolices in Vitro and in Vivo
}

\author{
Fadel Y. S. Al-Arabi ${ }^{1}{ }^{2 *}$, Aidah M. Ali ${ }^{3}$, Gozif Mohammed N. Omar ${ }^{1,4}$, Mansour \\ Abdulnabi H. Mehdi1 ${ }^{2}$, Mohammed Mohsen ${ }^{5}$, Mazahar Farooqui ${ }^{6}$,Vidya Pradhan ${ }^{1}$ \\ ${ }^{I}$ Department of Biology, Faculty of Education-Rdfan, Aden University, Aden, Yemen \\ ${ }^{2}$ Department of Zoology, Dr. Rafiq Zakaria College for Women, Aurangabad 431001 India \\ ${ }^{3}$ Department of Microbiology, Dr. Babasaheb Ambedkar Marathwada University, Osmanabad, Campus, India. \\ ${ }^{4}$ Department of Biochemistry, Dr. Babasaheb Ambedkar Marathwada University, Aurangabad, India. \\ ${ }^{5}$ Department of Chemistry, Dr. Rafiq Zakaria College for Women, Aurangabad 431001, India \\ ${ }^{6}$ Maulana Azad College of Arts Science \& Commerce Aurangabad 431001, India
}

Received: 13/12/2020

Accepted: 26/3/2021

\begin{abstract}
Echinococcosis is a common parasitic disease in humans and ruminants; it is considered as a health and economic problem in most parts of the world. The present study aims to evaluate the in vitro and in vivo scolicidal effects of Psidium guajava extracts on the protoscolices from hydatid cysts of Echinococcus granulosus. Protoscolices were aseptically aspirated from the livers of naturally infected sheep. Various concentrations of the extract were used for 6-48hrs. Eosin staining $(0.1 \%)$ was used to determine the viability of protoscolices. The findings showed that the extract at the concentrations of $100 \mathrm{mg} / \mathrm{ml}$ killed $100 \%$ protoscolices after $48 \mathrm{hrs}$. However, the concentrations of 75 and $50 \mathrm{mg} / \mathrm{ml}$ were not effective in killing the protoscolices after $48 \mathrm{hrs}$. of exposure. The results of this investigation demonstrated that $P$. guajava could be used as a natural source for the production of new scolicidal agents.
\end{abstract}

Keywords: Echinococcus granulosus, protoscolices, Psidium guajava, leaves extract.

\section{INTRODUCTION}

Hydatid is a common parasitic disease in humans and ruminants; it is a health and economic problem in most parts of the world [1]. Hydatidosis is particularly prevalent in rural areas where cattle, especially sheep and dogs, are abundant. The parasite needs to complete its life cycle to a host of sheep, goats, camels, pigs, horses, donkeys, monkeys and other ruminant animals to survive [2]. It is transmitted from carnivores to humans and herbivorous animals [3], where it develops to the larval stage of E. granulosus. This parasite, which belongs to the phylum Platyhelminthes of the class Cestoda, infects the small intestine of carnivores [4].

Guava (Psidium guajava Linn.) is a plant that belongs to the family Myrtaceae. It is originated in tropical South America and grows wild in Bangladesh, India, Thailand, Brazil, Florida, West Indies, California, and several other countries [5]. P. guajava is a small tree which is $10 \mathrm{~m}$ high, with thin, smooth, patchy, peeling bark. The leaves are opposite, shortpetiolate. The blade is oval with prominent pinnate veins, $5-15 \mathrm{~cm}$ long. The flowers are somewhat showy; the petals are whitish and up to $2 \mathrm{~cm}$ long; the stamens are numerous [6].

\footnotetext{
*Email: alaraby1100@gmail.com
} 
Guava is an important plant that is used traditionally for medicinal purposes. It is used as an important food as well as a medicinal plant in tropical and subtropical countries; therefore, it has also the name of the poor man's apple. Native to tropical areas from Southern Mexico to Northern South America, guava trees have been grown by many other countries that have tropical and subtropical climates, thus allowing widespread production around the world [7]. India is the major world producer of guava [8].

The phytochemical analysis shows the presence of flavonoids, tannins, saponins, triterpenies, glycosides, sterols, alkaloids, carbohydrates, phlobatannins, terpenoids, , and polyphenol in the plant extract [9].

Guava contains dietary fiber, protein, calcium, phosphorus, potassium, copper, iron, vitamin A, vitamin B1, vitamin C, vitamin B2, vitamin B3, and folic acid [6]. Guava has many benefits in our lives. Its fruits are used as food, while its wood is used in construction. Its leaves, roots, and seeds are also used in the treatment of many diseases. Its extracts showed active antibiotic effects [10,11]. Also, these extracts were used against insects [12] and against various types of human parasites, where it showed activity against toxoplasmosis [13], Trypanosoma brucei [14], and malaria [15].

It was noted through studies conducted on the extracts of guava leaves that they have effects against various types of cancer, including those of colon, rectum, benign breast [16], ovary, lung, prostate, and kidney, as well as leukemia [17]. In addition, the extracts of leaves prevented tooth decay and are used as an anti-inflammatory agent against teeth gums and acne $[18,19]$. Leaf extracts also showed activities against fungi [20, 21]. Guava leaves also have anti-ulcer activities by protecting the mucosa of the stomach through the action of flavonoids [22]. They also have the ability to heal wounds, inhibit diarrhea, and relieve menstrual pain, along with a broad-spectrum of other medicinal uses, including their use as anticonvulsant [19].

The importance of this study is that it shows both the in vitro and in vivo effects of the alcoholic and aqueous extracts of Psidium guajava leaves on the vitality of the protoscolices of Echinococcus granulosus of sheep origin.

MATERIALS AND METHODS

Preparation of plant extracts

Aqueous extract

The leaves of the plant under study were obtained from the campus of Dr. Rafiq Zakaria College for Women, Aurangabad, India, adapting the method followed by Mehdi et al. [23]. The aqueous extract of the leaves of $P$. guajava plant was prepared by mixing $40 \mathrm{~g}$ of leaves powder and $400 \mathrm{ml}$ of distilled water. The mixture was stirred by a magnetic stirrer for 24 hours. Then, the mixture was filtered through four pieces of medical gauze and centrifuged at a speed of $3000 \mathrm{rpm}$ for 10 minutes. After that, the mixture was placed in Petri dishes and dried in an oven at $40 \mathrm{C}^{\circ}$. Finally, the extract was scraped and collected in clean glass vials and kept in refrigerator for use [24].

\section{Alcoholic extract}

The plant leaves powder (40gm) was placed in a Soxhlet apparatus. Then, $400 \mathrm{ml}$ ethyl alcohol of $70 \%$ concentration was added and the mixture was left undisturbed. The solvent was then evaporated by using a rotary evaporator [25]. The mixture was finally placed in clean Petri dishes.

\section{The source of the hydatid cyst}

The hydatid cysts were obtained from the sheep of the butchery of Al-Basateen, the city of Aden, Yemen. The cysts were then transferred to the laboratories of the Faculty of Science, University of Aden, Yemen (Figure 1). 


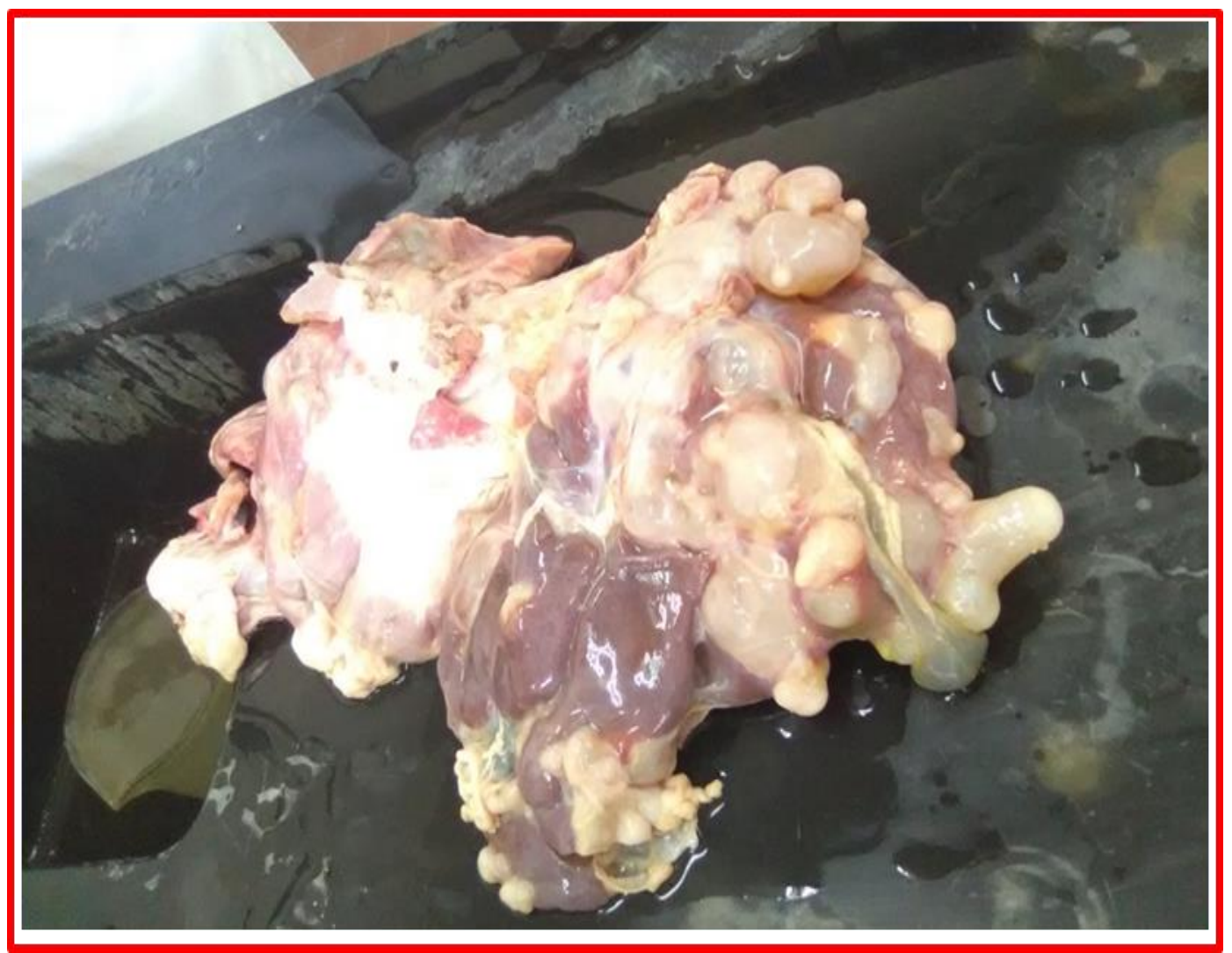

Figure 1- Hydatid cysts in liver

\section{Collection of protoscolices}

The method of Niazi et al. [26] was used to obtain the protoscolices. The hydatid cyst was sterilized twice with ethyl alcohol $(70 \%)$ and the cyst fluid was removed by a sterile syringe. The cyst was washed internally with $\mathrm{pH} 7.2$ and the antibiotic was penicillin IU20000 and streptomycin $1 \mathrm{~g} / \mathrm{l}$. The liquid was then discarded in test tubes and centrifuged at $3000 \mathrm{rpm}$. The protoscolices were examined under a light microscope.

\section{Evaluation of the vitality of the protoscolices}

The vitality of the protoscolices were estimated by using the method of Barzinji et al. [27]. 20 microliters of the protoscolices were placed on a clean glass slide, to which an equal volume of the aqueous eosin stain was added and examined under the microscope. Green protoscolices were counted as vital whereas red ones were counted as dead. The vitality of the protoscolices was taken into consideration because it is an important indicator of infection severity. The percentage of live protoscolices in the sample was calculated by dividing the number of live protoscolices to the total number of calculated headings and multiplying the result by 100 . The process was repeated three times and the survival rate was extracted. The percentage of vital protoscolices was calculated after each exposure period.

\section{Laboratory animals}

In this study, albino rats Rattus norvegicus obtained from the laboratory of the Faculty of Science, University of Aden-Yemen, were used. They were grown and reproduced in the standard conditions of the animal house, being provided with water and food ad libitum. The food consisted of a concentrated mash of protein and dry milk. 


\section{Implantation of protoscolices in laboratory animals}

In order to determine the in vivo effects of the plant extract on the vitality, growth, and development of the protoscolices of sheep origin [28], rats were injected with different mixtures of protoscolices and leaf extract. The concentration and the duration of treatment were determined based on the results of the in vitro screening of the effects of this extract on the protoscolices. The detailed procedure applied is as follows. Protoscolices of sheep origin were treated with the alcoholic extract of $P$. guajava at $100 \mathrm{mg} / \mathrm{ml}$ for 48 hours and then injected into the peritoneum of four rats (2000 protoscolices/rat). Similarly, protoscolices were treated with the aqueous extract of P. guajava $(100 \mathrm{mg} / \mathrm{ml})$ for 48 hours and then injected into the peritoneum of four rats (2000 protoscolices/rat). As a control group, protoscolices not treated with $P$. guajava extracts were injected into the peritoneum of four rats (2000 protoscolices/ rat).

\section{Anatomical examination of rats}

The rats that had been injected with the protoscolices of sheep origin were treated with the extracts under study after three months. The secondary hydatid cysts were investigated in the peritoneum, liver, lungs, kidneys and other parts of the body using a magnifying lens. Pictures were taken for the rats of the two groups.

\section{Statistical analysis}

The results of the present study were analyzed by Genstat ${ }^{\circledR}$ (Version 5.2) using general treatment structure (no blocking), factorial experiment, with 3 replicates. The least significant different (LSD) test was used to test the differences between means (groups) which were considered significant at $\mathrm{P} \leq 0.05$.

\section{RESULTS}

\section{Effects of alcoholic and aqueous leaf extracts of $P$. guajava on the protoscolices in vitro.}

Through the results, a clear effect of the plant extracts of $P$. guajava leaves appears in killing the protoscolices. The results of the analysis of variance shown in Table 1 reveal significant differences between the concentrations and exposure periods at the probability level $\mathrm{P}<0.05$. The concentration of $100 \mathrm{mg} / \mathrm{ml}$ of both aqueous and alcoholic extract showed its superiority in reducing the vitality of the protoscolices to zero at 48 hours compared with the control group, which was vital at $96.33 \%$ and $96 \%$, respectively. The concentration of $75 \mathrm{mg} / \mathrm{ml}$ followed as the second most effective. The lowest rate of killing of protoscolices was at the concentration of $50 \mathrm{mg} / \mathrm{ml}$ at 12 hours, where the rate reached in the aqueous and alcoholic extract to $8.33 \%$ and $\%$ and $9.33 \%$, respectively, compared to the control group $(93.33 \%$ and $94.33 \%$, respectively). Also, the table shows that the exposure periods have exceeded 48 hours from the other periods. It was also noticed that when the concentration and the exposure period increases, the death-rate of protoscolices increases (Figures 2,3). The lowest rate of killing of protoscolices was at the concentration of $50 \mathrm{mg} / \mathrm{ml}$ at 6 hours, which reached 9.33 $\%$ and $8.33 \%$ uisng alcoholic and aqueous extracts, respectively, compared to the control group. 
Table 1-Effect of the alcoholic and aqueous extract of $P$. guajava on the origin of sheep protoscolices in vitro

\begin{tabular}{|c|c|c|c|c|c|c|c|}
\hline \multirow{3}{*}{ Extract } & \multirow{3}{*}{ Concentration } & \multirow{3}{*}{ Control } & \multicolumn{4}{|c|}{ Time /Hour } & \multirow{3}{*}{ Means } \\
\hline & & & $6 \mathrm{hrs}$ & $12 \mathrm{hrs}$ & 24 hrs & $48 \mathrm{hrs}$ & \\
\hline & & & М\% & M\% & М\% & М\% & \\
\hline \multirow{3}{*}{$\begin{array}{l}\text { Alcoholic } \\
\text { Extract }\end{array}$} & $100 \mathrm{mg} / \mathrm{ml}$ & 96.00 & 18.00 & 35.33 & 66.00 & 100.00 & 63.07 \\
\hline & $75 \mathrm{mg} / \mathrm{ml}$ & 95.33 & 14.33 & 24.00 & 49.00 & 97.67 & 56.07 \\
\hline & $50 \mathrm{mg} / \mathrm{ml}$ & 94.33 & 9.33 & 16.00 & 36.67 & 90.33 & 49.33 \\
\hline \multicolumn{2}{|c|}{ Mean } & 95.22 & 13.89 & 25.11 & 50.56 & 96.00 & 56.15 \\
\hline \multirow{3}{*}{$\begin{array}{l}\text { Aqueous } \\
\text { Extract }\end{array}$} & $100 \mathrm{mg} / \mathrm{ml}$ & 96.33 & 16.33 & 33.33 & 61.00 & 100.00 & 61.40 \\
\hline & $75 \mathrm{mg} / \mathrm{ml}$ & 95.33 & 11.67 & 23.67 & 45.33 & 95.00 & 54.20 \\
\hline & $50 \mathrm{mg} / \mathrm{ml}$ & 93.33 & 8.33 & 16.00 & 31.67 & 87.33 & 47.33 \\
\hline \multicolumn{2}{|c|}{ Mean } & 95.00 & 12.11 & 24.33 & 46.00 & 94.11 & 54.31 \\
\hline \multirow{3}{*}{ Con*T } & $100 \mathrm{mg} / \mathrm{ml}$ & 96.17 & 17.17 & 34.33 & 63.50 & 100.00 & 62.23 \\
\hline & $75 \mathrm{mg} / \mathrm{ml}$ & 95.33 & 13.00 & 23.83 & 47.17 & 96.33 & 55.13 \\
\hline & $50 \mathrm{mg} / \mathrm{ml}$ & 93.83 & 8.83 & 16.00 & 34.17 & 88.83 & 48.33 \\
\hline \multicolumn{2}{|c|}{ Means of Time } & 95.11 & 13.00 & 24.72 & 48.28 & 95.05 & \\
\hline LSD 5\% & \multicolumn{7}{|c|}{$\begin{array}{c}\mathrm{EX}=1.726, \mathrm{C}=2.113, \mathrm{~T}=2.728, \mathrm{EX} * \mathrm{C}=2.989, \mathrm{EX} * \mathrm{~T}=3.859, \mathrm{C} * \mathrm{~T}=4.726, \\
\mathrm{EX}{ }^{*} \mathrm{C}^{*} \mathrm{~T}=6.683 .\end{array}$} \\
\hline $\mathrm{CV}$ & \multicolumn{7}{|c|}{7.4} \\
\hline
\end{tabular}

Least Significant Difference (LSD); EX (Extract); T (Time); C (Concentration); CV (Coefficient of Variation); M (Mortality).

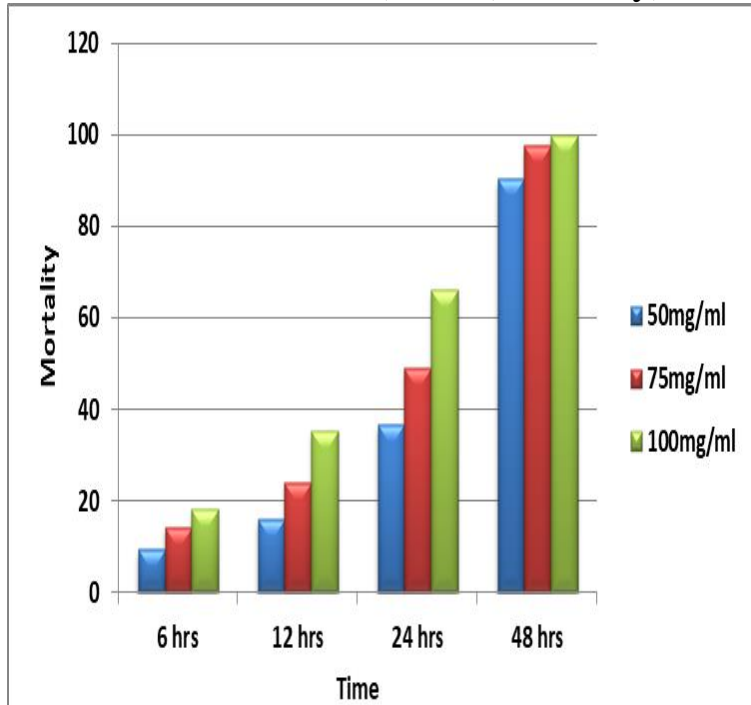

Figure 2- Effect of alcoholic extract of $P$. guajava on sheep origin protoscolices in vitro.

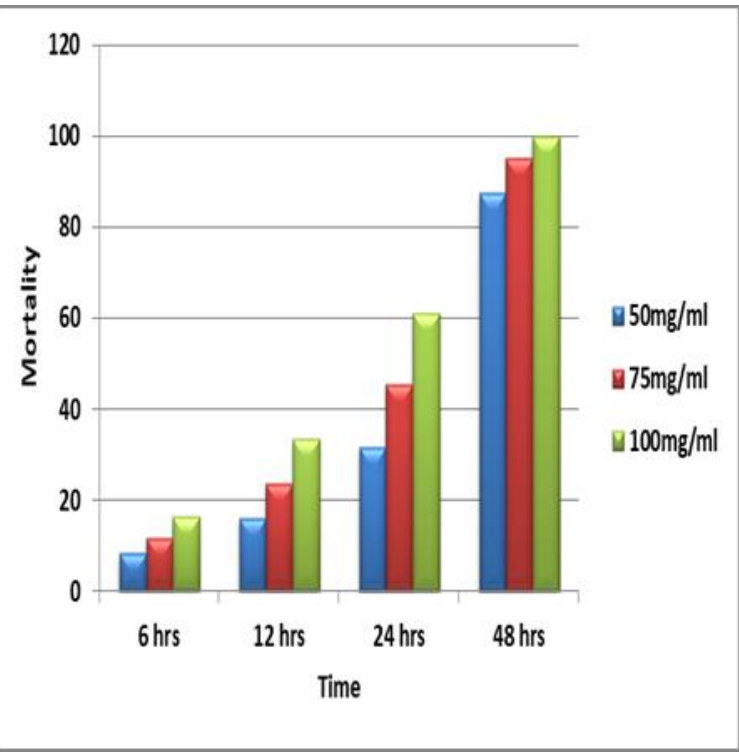

Figure 3- Effect of aqueous extract of $P$. guajava on sheep origin protoscolices in vitro. 
Effect of the aqueous and alcoholic extracts of $P$. guajava on the protoscolices in vivo After performing the above mentioned experiments related with the effects of alcoholic and aqueous extracts of $P$. guajava plant on the vitality of the protoscolices in vitro and the observation of the mortality rate of the protoscolices in vitro, the protoscolices treated with the extracts under this study were injected into the peritoneum of the laboratory rats to check the effect of these substances on the mortality of the protoscolices in vivo. Three months later, the rats were dissected to investigate the presence and growth of secondary hydatid cysts (Figures 4, 5). The hydatid cysts were clearly visible in the laboratory rats injected with the non-treated extracts using the substances used in this study, as compared to the control group (Figure 6).

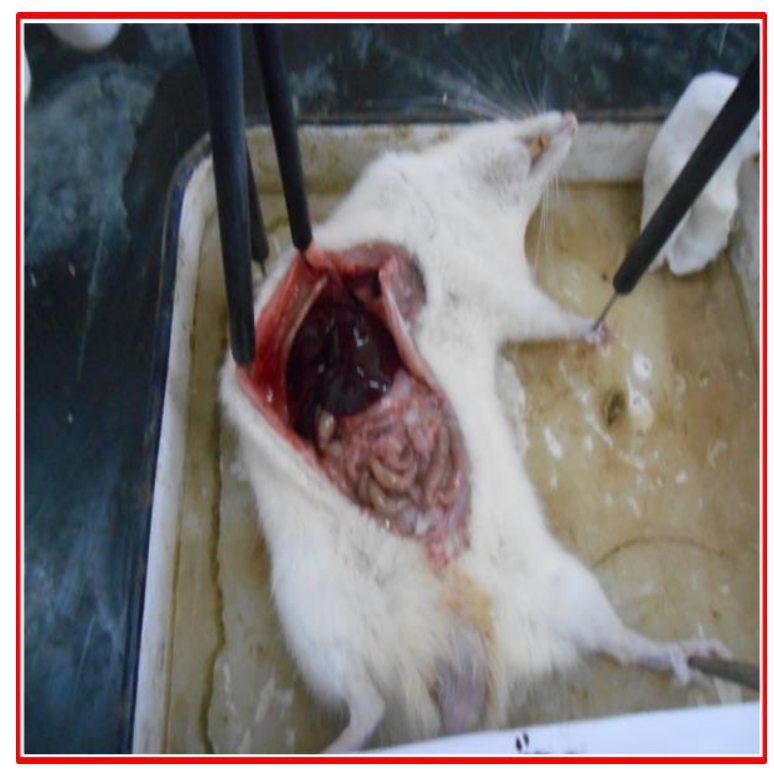

Figure 4- Rat treated with alcoholic extract of $P$. guajava.

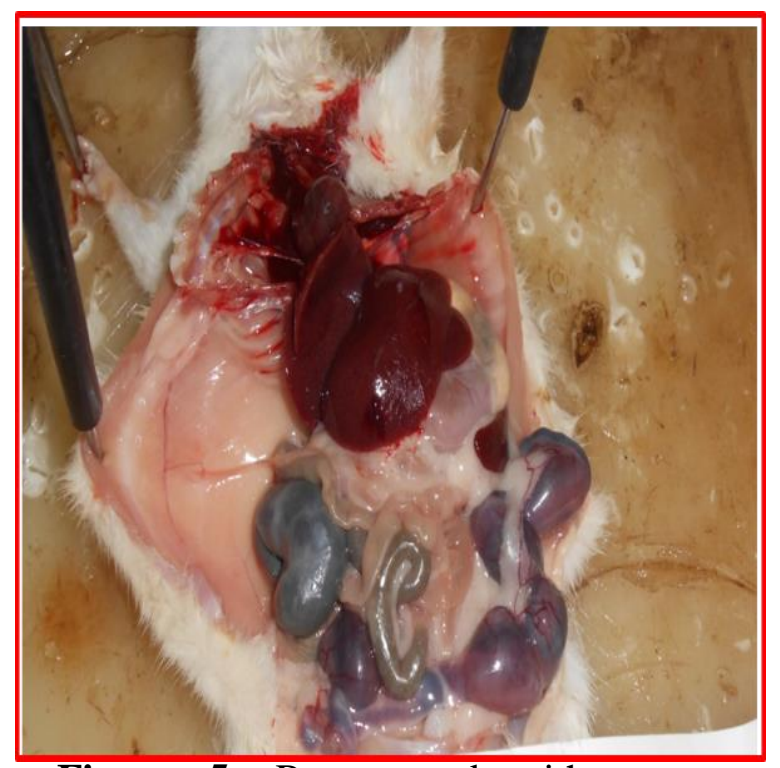

Figure 5- Rat treated with aqueous extract of $P$. guajava.

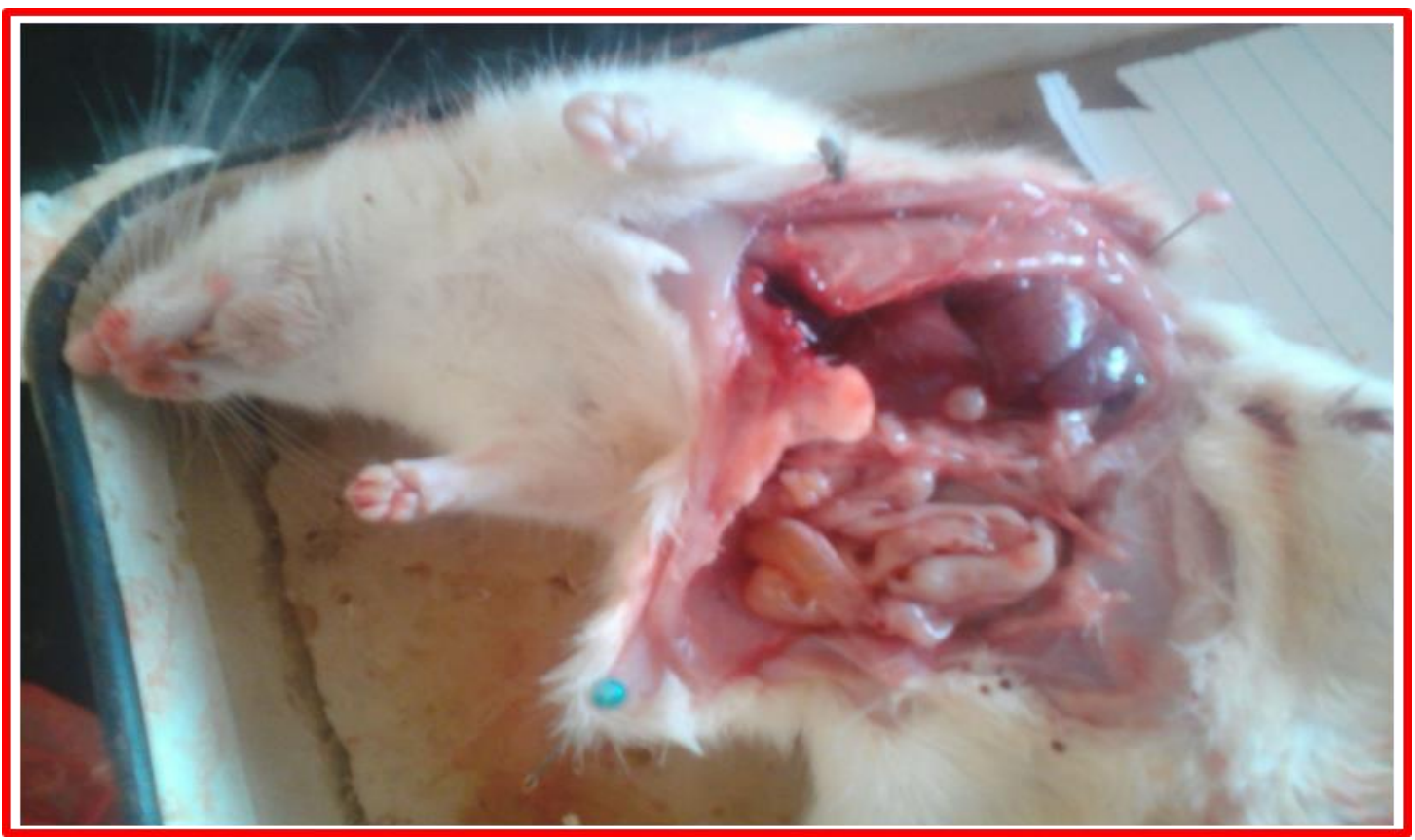

Figure 6-Control group. 


\section{DISCUSSION}

The results of this study were similar to the results obtained by Mustafa in terms of time. When he used aqueous extraction of Cyperus longous plant at concentration of $20 \%$ after passing 48 hours, the protoscolices were killed [29].

In addition to that, these results are similar to the result obtained by Al-Hasnawi et al., when they used the boiled broccoli extract at a concentration of $0.3 \mathrm{~g} / \mathrm{ml}$, as it led to the complete death of protoscolices of human origin after 168 hours of treatment [30]. The results of this study were superior to the results of the study conducted by Xing et al., who used $\mathrm{NaASO}_{2}$ at a concentration of $20 \mu \mathrm{M}$. They obtained a complete death rate for protoscolices after 6 days [31]. They also outperformed the results of a study conducted by Khalaf et al., who used alcohol extract of Cladophora crispola at a concentration of $300 \mu \mathrm{g} / \mathrm{ml}$ that led to complete death of the protoscolices after 3 days of treatment [32].

In the previous studies, guava leaf acetone extraction showed killer activities against Hippobosca maculate fly adults [12]. Ethanol extraction of guava leaves inhibited the growth of Trypanosome bruci [15]. The leaf extract works as an anti-malaria agent due to its inhibitory activity, while guava oil works against Toxoplasmosis caused by the growth of Toxoplasma gandhi [13]. Guava leave extracts were also used against trypanosomiasis and Hymenolepis dimlnuta in mice [33, 34].

The mortality rate of the protoscolices treated by $P$. guajava plant extracts can be attributed to its inclusion of active substances, such as alkaloids whose effect is a consequence of their reaction with the metabolic protein required for the vitality of the protoscolices. This leads to the destruction of the cell wall and its proteins till the protoscolices die [35]. The mortality rate of the protoscolices treated with aqueous and alcoholic extracts of $P$. guajava leaves can also be attributed to the tannins which may penetrate the cell membrane and block the active sites of some enzymes inside the cell, which are necessary for the growth of the parasites [36]. The death of the parasite can be due to phenol substance which has an effect on the acetyl cholinesterase enzyme that controls the flexibility and permeability of the cell membrane. Phenols make the membrane lose permeability and regulation for some substances, which results in passing of various toxic substances without regulation, leading to the parasite death [37]. The death of the parasites is attributed to flavonoids, which can reduce sugars, leading to a reduction of carbohydrate metabolism and thus a decrease in ATP [38].

\section{CONCLUSIONS}

Through the results obtained from the current study, the following can be inferred. The Psidium guajava extract has a clear effect in the reduction of the vitality of the protoscolices following in vitro treatment for a short period of time. Lack of growth of secondary hydatid cysts in the rats programmed with the protoscolices treated with the Psidium guajava extracts in this study suggests the ability of the plant extracts to kill the protoscolices completely.

\section{Ethics approval}

Institutional guidelines for the care and use of animals were followed. All procedures performed in the study and involved animals were in accordance with the ethical standards of the institution or practice at which the study was conducted (date 16/08/2018).

\section{Financial support}

None.

\section{Conflict of interest}

There was no conflict of interest among the authors in presenting this article for publication. 


\section{ACKNOWLEDGMENTS}

Very special gratitude to Dr. Yaqoub Abdulla Qassem, Dean of the Faculty of Education Aden, University of Aden. We are also grateful to Dr. Mohammed Hussein, Dean of the Faculty of Science, Aden. Words of thanks go to Dr. Khaled Nasher, Dr. Shaif Saleh, Dr. Ibtisam Al Shiko, and Dr. Ahmed Al-Serhi, for their support in completing this research.

\section{REFERENCES}

[1] M. H. Kohansal, A. Nourian, M. T. Rahimi, A. Daryani, A. Spotin, and E. J. A. t. Ahmadpour, "Natural products applied against hydatid cyst protoscolices: a review of past to present," Acta Trop, vol. 176, pp. 385-394, 2017.

[2] K. Kismet et al., "The effects of scolicidal agent propolis on liver and biliary tree," Journal of Gastrointestinal Surgery, vol. 12, no. 8, pp. 1406-1411, 2008.

[3] S. Nepalia, A. Joshi, A. Shende, and S. J. J.-A. O. P. O. I. Sharma, "Management of echinococcosis," Journal-Association of Physicians of India, vol. 54, no. N, p. 458, 2006.

[4] J. Eckert, F. Conraths, and K. J. I. j. f. p. Tackmann, "Echinococcosis: an emerging or reemerging zoonosis?," International journal for parasitology, vol. 30, no. 12-13, pp. 1283-1294, 2000.

[5] P. Mittal, V. Gupta, G. Kaur, A. K. Garg, and A. J. I. Singh, "Phytochemistry and pharmacological activities of Psidium guajava," IJPSR, vol. 1, no. 9, pp. 9-19, 2010.

[6] R. Regina, M. J. I. J. o. M. R. Santosh, and Development, "The active potential of Guava Psidium guajava (L.) leaves extract and its anticancer activity," International Journal of Multidisciplinary Research and Development, vol. 4, no. 7, pp. 475-478, 2017.

[7] E. Díaz-de-Cerio, V. Verardo, A. M. Gómez-Caravaca, A. Fernández-Gutiérrez, and A. J. I. j. o. m. s. Segura-Carretero, "Health effects of Psidium guajava L. Leaves: An overview of the last decade," International journal of molecular sciences, vol. 18, no. 4, p. 897, 2017.

[8] B. Biswas, K. Rogers, F. McLaughlin, D. Daniels, and A. J. I. j. o. m. Yadav, "Antimicrobial activities of leaf extracts of guava (Psidium guajava L.) on two gram-negative and gram-positive bacteria," International journal of microbiology, vol. 2013, 2013.

[9] N. Dwivedi, G. Patel, N. Dwivedi, and I. J. I. J. R. A. P. Tripathi, "Physicochemical and phytochemical studies of Psidium guajava L," Int J Res Ayurveda Pharm, vol. 8, pp. 102-7, 2017.

[10] R. Milyani and N. J. A. Ashy, "Inhibitory effect of some plant extracts on clinical isolates of Staphylococcus aureus," Afr J Microbiol Res, vol. 6, no. 40, pp. 6822-6829, 2012.

[11] K. Anas, P. Jayasree, T. Vijayakumar, and P. Kumar, "In vitro antibacterial activity of Psidium guajava Linn. leaf extract on clinical isolates of multidrug resistant Staphylococcus aureus," Indian Journal of Experimental Biology, vol. 46, no. 01, pp. 41-46, 2008.

[12] A. A. Zahir et al., "Evaluation of botanical extracts against Haemaphysalis bispinosa Neumann and Hippobosca maculata Leach," Parasitology research, vol. 107, no. 3, pp. 585-592, 2010.

[13] W. C. Lee, R. Mahmud, R. Noordin, S. Pillai Piaru, S. Perumal, and S. J. J. o. E. O. B. P. Ismail, "Free radicals scavenging activity, cytotoxicity and anti-parasitic activity of essential oil of Psidium guajava L. leaves against Toxoplasma gondii," Journal of Essential Oil Bearing Plants, vol. 16, no. 1, pp. 32-38, 2013.

[14] O. S. Adeyemi, M. L. Sykes, M. A. Akanji, and V. M. J. V. a. Avery, "Anti-trypanosomal and cytotoxic activity of ethanolic extracts of Psidium guajava leaves in Alamar Blue based assays," Veterinarski arhiv, vol. 81, no. 5, pp. 623-633, 2011.

[15] N. K. Kaushik et al., "Evaluation of antiplasmodial activity of medicinal plants from North Indian Buchpora and South Indian Eastern Ghats," Malaria Journal, vol. 14, no. 1, pp. 1-8, 2015.

[16] T. V. Braga et al., "Antioxidant, antibacterial and antitumor activity of ethanolic extract of the Psidium guajava leaves," American Journal of Plant Sciences, vol. 5, no. 23, p. 3492, 2014.

[17] L. Rizzo et al., "In vitro, in vivo and in silico analysis of the anticancer and estrogen-like activity of guava leaf extracts," Current Medicinal Chemistry, vol. 21, no. 20, pp. 2322-2330, 2014.

[18] S. Thalikunnil, A. Ashok, and K. J. I. J. P. P. S. Sukesh, "Screening of psidium gaujava for effective phytomedicines and study on its antibacterial effect against dental caries bacteria," Int $J$ Pharm Pharm Sci, vol. 4, pp. 400-401, 2012. 
[19] S. Jayakumari, J. Anbu, V. Ravichandiran, A. Anjana, G. Siva Kumar, and S. J. I. J. P. P. S. Maharaj, "Antiulcerogenic and free radical scavenging activity of flavonoid fraction of Psidium guajava Linn leaves," Int J Pharm Pharm Sci, vol. 4, pp. 170-174, 2012.

[20] P.-M. Beatriz, V.-V. Ezequiel, and C.-R. J. J. o. M. P. R. Pilar, "Antifungal activity of Psidium guajava organic extracts against dermatophytic fungi," Journal of Medicinal Plants Research, vol. 6, no. 41, pp. 5435-5438, 2012.

[21] S. Suwanmanee, T. Kitisin, N. J. E.-B. C. Luplertlop, and A. Medicine, "In vitro screening of 10 edible Thai plants for potential antifungal properties," Evidence-Based Complementary and Alternative Medicine, vol. 2014, 2014.

[22] S. V. Doubova et al., "Effect of a Psidii guajavae folium extract in the treatment of primary dysmenorrhea: a randomized clinical trial," Journal Ethnopharmacology, vol. 110, no. 2, pp. 305$310,2007$.

[23] M. A. H. Mehdi, F. Alarabi, G. M. N. Omar, V. Pradhan, and Pharmacology, "Effect of extracts on haematological parameters in albino rats Tamarindus indica infected with parasite Entamoeba histolytica," Asian Journal of Pharmacy and Pharmacology, vol. 5, no. 5, pp. 889-894, 2019.

[24] M. A. H. Mehdi, F. Y. Alarabi, G. M. N. Omar, K. N. Q. Salem, V. J. R. J. o. P. Pradhan, "Evaluation of haematological changes in Entamoeba histolytica-infected rats administered with extracts of Ziziphus mauritiana leaves," Research Journal of Pharmacy and Technology, vol. 13, no. 9, pp. 4105-4110, 2020.

[25] M. A. H. Mehdi and V. J. M. S. J. Pradhan, "The antiamoebic potential of aqueous extract of Pancratium maximum bulbs in rats infected with Entamoeba histolytica," Mukt Shabd Journal,vol. 9, no. 6, pp. 457-466, 2020.

[26] M. Niazi et al., "In vitro and ex vivo scolicidal effects of Olea europaea L. to inactivate the protoscolecs during hydatid cyst surgery," Annals of Medicine and Surgery, vol. 42, pp. 7-10, 2019.

[27] A. K. Raoof Barzinji, R. A. Mothana, and A. K. J. E. J. o. B. Nasher, "Effect of leaf extracts of Dendrosicyos socotrana and Jatropha unicostata on the viability of Echinococcus granulosus protoscoleces," Eur Asian Journal of Bio Sciences, vol. 3, pp. 122-129, 2009.

[28] F. Al-Arabi, M. Mehdi, M. Farooqui, and V. J. Pradhan, "The effect of Aloe vera extracts on the viability of Echinococcus granulosus protoscolices," International Journal of Pharmaceutical Research, vol. 10, no. 4, pp. 184-189, 2019.

[29] F. A. J. R. Jabbar-Mustafa, "The Effect Of Aqueous And Alcoholic Extract Of Cyperus Longous (Cyperaceae) And Tow Drugs (Tinidazole And Praziquantel) On Killing The Protoscolices Of Echinococcus Granulosus In Vitro," Basrah Journal of Veterinary Research, vol. 8, no. 2, 2009.

[30] N. Z. S. S. Al-Hasnawi, A. K. Al-Hamairy, H. J. M. J. I. J. o. F. M. Altameme, and Toxicology, "Evaluation Activity of Boiled Aqueous Extract of Broccoli Flower Plant (Brassica Oleraceae L. Var. Italic) And Albendazole Drug Against the Protoscolices in Vitro," Indian Journal of Forensic Medicine \& Toxicology, vol. 14, no. 4, p. 2461, 2020.

[31] G. Xing et al., "In vitro effect of sodium arsenite on Echinococcus granulosus protoscoleces," Molecular and Biochemical Parasitology, vol. 207, no. 2, pp. 49-55, 2016.

[32] A. K. KHALAF, "In vitro and in vivo activity of (2-deca-3, d-dienyloxy) carbonyl benzeoic acid extracted from cladophora crispata against the spleenic hydatid cyst." Journal of International Academic Research for Multidisciplinary, vol. 3, pp. 339-348, 2015.

[33] O. S. Adeyemi, M. Akanji, and S. J. J. o. m. p. r. Oguntoye, "Ethanolic leaf extract of Psidium guajava: Phytochemical and trypanocidal activity in rats infected with Trypanosoma brucei brucei," Journal of Medicinal Plants Research, vol. 3, no. 5, pp. 420-423, 2009.

[34] T. V. Tangpu and A. K. J. I. J. o. P. Yadav, "Anticestodal efficacy of Psidium guajava against experimental Hymenolepis diminuta infection in rats," Indian Journal of Pharmacology, vol. 38, no. 1, p. 29, 2006.

[35] M. M. J. C. m. r. Cowan, "Plant products as antimicrobial agents," Clinical Microbiology Reviews, vol. 12, no. 4, pp. 564-582, 1999.

[36] M. A. H. Mehdi, V. Pradhan, K. N. Q. Salem, G. M. N. Omar, and F. J. E. J. o. B. Alarabi, "Effect of ethanol extract of Pancratium maximum bulbs on Entamoeba histolytica in vivo," European Journal of Biomedical, paragrammatical and Science, vol. 7, no. 12, pp. 317-322, 2020. 
[37] M. A. H. Mehdi, G. M. N. Omar, M. Farooqui, V. J. I. J. o. P. S. Pradhan, and Research, "Therapeutic effect of Tamarindus indica extracts on the pathogenesis of Entamoeba histolytica in-vivo," International Journal of Pharmaceutical Sciences and Research, vol. 10, no. 7, pp. 3250-3256, 2019.

[38] M. A. H. Mehdi, F. Alarabi, M. Farooqui, and V. J. A. J. P. C. R. Pradhan, "Phytochemical screening and antiamebic studies of Tamarindus indica of leaves extract," Asian J. Pharm. Clin. Res, vol. 12, no. 2, pp. 507-512, 2019. 